\title{
First report of Basella rugose mosaic virus infecting Basella alba in Nigeria
}

\author{
Adedapo Olutola Adediji ${ }^{1}$ (D) - Gabriel Ifo Atiri ${ }^{1}$
}

Received: 28 January 2020 / Accepted: 4 February 2020 / Published online: 17 February 2020

(C) Società Italiana di Patologia Vegetale (S.I.Pa.V.) 2020

Keywords Malabar spinach $\cdot$ Potyvirus $\cdot$ Coat protein

Malabar spinach (Basella alba) is a popular potherb in Nigeria, grown in commercial farms and around household gardens. In 2018, virus-like symptoms such as leaf malformation and mild mosaic were observed on $B$. alba plants in a backyard garden in Ibadan, Oyo State, Nigeria. Six symptomatic leaf samples were obtained from three plants and three of them tested positive in DAS-ELISA to monoclonal antibodies (Agdia Inc., Elkhart, USA) specific to potyviruses. Total nucleic were extracted from infected plants using the cetyl trimethyl ammonium bromide method and RT-PCR was performed using degenerate primers PotyCP (5' TGGTGYATGANAAYGGNACNT-3') and Oligo-dT-potyR (5'-CCCAGTCACGACTTTTTTTTTT-3') (Sudheera et al. 2014) to amplify a partial coat protein (CP) gene and the 3' end untranslated region of the potyvirus genomic RNA. Products of approximately $800 \mathrm{bp}$ were amplified and an amplicon from a sample, Dg-Ke, was bi-directionally sequenced. The poly(A) tail was trimmed from the sequence and deposited in GenBank under accession number MN996303. Nucleotide and amino acid sequence analysis of the partial CP gene showed $96.1 \%$ and $97.9 \%$ identities, respectively, with an isolate of Basella rugose mosaic virus (BaRMV-BR; DQ821939) infecting B. rubra in Taiwan
(Huang and Chang 2006). To our knowledge, this is the first report of a potyvirus infecting $B$. alba in Nigeria. Although a cucumber mosaic virus isolate has recently been reported from B. alba in Nigeria (Adediji 2019), the presence of BaRMV suggests that the plant is a host to multiple viruses.

\section{References}

Adediji AO (2019) Molecular detection of Cucumber mosaic virus from Basella alba, Telfairia occidentalis and Talinum fruticosum in Nigeria. J Plant Prot Res 59(2):177-184. https://doi.org/10.24425/ jppr.2019.129282

Huang CH, Chang YC (2006) Basella rugose mosaic virus, a new potyvirus infects Basella rubra. Plant Pathol 55:819. https://doi. org/10.1111/j.1365-3059.2006.01477.x

Sudheera Y, Vishnu Vardhan GP, Hema M, Krishna Reddy M, Sreenivasulu P (2014) Characterization of a potyvirus associated with yellow mosaic disease of jasmine (Jasminum sambac L.) in Andhra Pradesh, India. Vir Dis 25(3):394-397. https://doi.org/10. 1007/s13337-014-0193-0

Publisher's note Springer Nature remains neutral with regard to jurisdictional claims in published maps and institutional affiliations.
Adedapo Olutola Adediji

adedapo.adediji@gmail.com

Gabriel Ifo Atiri

gabatiri@yahoo.com

1 Department of Crop Protection and Environmental Biology, Faculty of Agriculture, University of Ibadan, Ibadan, Oyo State, Nigeria 